\title{
Landscape-Ecological Approach to Spatial Planning as a Tool to Minimize Socio-Ecological Conflicts: Case Study of Agrolandscape in the Taiga Zone of Russia
}

\author{
Alexander Khoroshev \\ Faculty of Geography, Lomonosov Moscow State University, Moscow 119991, Russia; avkh1970@yandex.ru
}

Received: 15 April 2020; Accepted: 4 June 2020; Published: 10 June 2020

\begin{abstract}
Landscape heterogeneity generates significant influences on economic activity. Present-day publications in landscape planning focus more and more on a participatory approach and a communication process. By contrast, we focus on nature-based criteria aimed at proper adaptation of planning decisions to natural landscape patterns. The paper proposes the framework aimed at considering geographical context, matter flows, and dynamic processes in projecting ecological network and perfect sites for various land use types as well as for choosing appropriate technologies. We use the example of a river basin in the taiga zone of European Russia, partially used for forestry and traditional agriculture. A landscape map, space images, and geochemical data are used to provide rationales for the necessary emergent effects resulting from proper proportions, neighborhoods, buffers, and shapes for lands use units. The proposed spatial arrangement of land use types and technologies ensures the coordination of socio-economic and ecological interests and preserves zonal background conditions, including runoff, soils, migration routes, and biodiversity. The allocation of arable lands and cutovers is aimed at minimizing undesirable matter flows that could cause qualitative changes in the geochemical environment.
\end{abstract}

Keywords: landscape planning; adaptation; taiga; agriculture; neighborhood; flow; buffer; ecological network

\section{Introduction}

The term "landscape planning" or "landscape-ecological planning" is widely used both in science and nature management [1-5]. Ndubisi [6] prefers the term "ecological planning" to emphasize the notion of relationships. We concur with Ndubisi [6] that landscape-ecological investigation is a scientific foundation for the planning decision that examines both the vertical and horizontal structure of landscapes. The landscape is a constant living test for spatial planning and it allows assessing the appropriateness or inconsistency of human practices [7]. A landscape is an entity whose geographic scale depends on what type of land use is in focus in a planning process [8]. However, the opposite is true as well: a landscape as a natural heterogeneous unit determines an appropriate scale for each type of land use. We proceed from the understanding of geographical landscape as a "genetically uniform territory with regular and typical occurrence of interrelated combinations of geological composition, landforms, surface and ground waters, microclimates, soil types, phytocoenoses and zoocoenoses" [9]. This definition is based on recognizing the decisive contribution of the abiotic template to spatial patterns of soils and vegetation. Human activity is believed to adapt to abiotically-induced patterns. The well-known definition of landscape in the European Landscape Convention reflects the different, clearly anthropocentric, view. However, human perception in most cases is closely related to natural patterns that may be identified in a more objective way following the definition by Solnetsev. Landscape 
is hierarchically organized. The school of landscape science developing in Russia since 1930s [10] commonly recognizes four subordinate levels related to the hierarchy of landforms. The level most appropriate for landscape planning with the common linear dimensions $0.1-10 \mathrm{~km}$ is referred to as urochishche, which is comparable to the German term nanogeochore [11] and the Australian land unit [12]. The examples are ravine, moraine hill, river terrace, and flat interfluve area. The smaller elementary units with common linear dimensions $0.01-1 \mathrm{~km}$ that are referred to as facies (comparable to ecotope in the German literature [11] and to site [12]) are too small for planning decisions.

Each hierarchical level of nature organization imposes certain framework conditions for the possible choice of planning decisions at the lower level [13]. Landscape planning is strong in producing area-specific results, which can be incorporated into implementation mechanisms, such as legally-binding land use planning, protected area designations or targeted agri-environmental schemes [14].

Landscape heterogeneity per se generates significant influences on economic activity. In fact, unfortunately, many policies drive towards production, protection or consumption, tending towards less diverse landscape patterns [15] though heterogeneity manifests itself in any case. Its underestimation can result in serious economic losses and ecological detriment.

Contemporary publications in landscape planning as well as presentations at the conferences focus more and more on a participatory approach and a communication process, which are extremely important under the conditions of dominance of lands in private property. A huge amount of studies was devoted to the influence of institutional conditions [8], participatory policy design for a multi-functional landscape $[7,16,17]$, farmers' land use decisions [18-20], methods for surveying between the local stakeholders and outside experts [21], and assisting administrators and stakeholders in the planning procedure [22]. However, the principal aim of landscape planning, in our opinion, is to adapt land use to natural units and to imitate natural flows and processes as perfectly as possible. Nature-based criteria for the planning decisions are diverse and need to be properly arranged in planning procedures.

The great challenge for landscape planning is the necessity to take into consideration the multifunctionality of landscapes [23,24]. Almost half a century ago the concept of differential land use supposed a higher ecological efficiency of multifunctional landscapes as compared to monofunctional ones [25]. The requirement for sustainability demands is to make a careful site-specific choice between mono-sectoral and multi-sectoral spatial solutions with due regard to landscape heterogeneity. The sectorial planning paradigm, e.g., in the forest sector, has prevailed throughout the 20th century and has resulted in a situation where a monofunctional land use strategy has been adopted as the most economically efficient with ignorance for other ecosystem services, e.g., non-timber resources, recreational, water-regulating, and climate-regulating $[8,26]$. This resulted in the rapid exhaustion of timber and non-timber resources, undesirable changes in runoff regime, higher vulnerability to natural disasters, and social conflicts $[27,28]$. Coordination of stakeholders' interests in space affects landscape state greatly, since perfect neighborhoods of land use units can generate the required emergent effect supporting normal functioning within the natural range of states. The example is the method of Ecological Risk Assessment (ERA), which is aimed at identifying not only ecologically sensitive and conflict areas, but also territories with mutually additive functions [24].

Thus, planning a landscape is a multifaceted challenge that inevitably deals with natural boundaries, lateral and radial interactions between landscape system components, and constant changes both in the configuration and internal properties of the components. The involvement of each land parcel in various types of geosystems requires searching criteria for identification of synergetic and dynamic effects that influence the efficiency and ecological safety of human activity.

The purpose of the research is to develop the landscape-ecological framework for spatial planning within the limits of a small river basin with a complex landscape structure. We will propose rationales for three types of planning decisions: (i) projecting an ecological network; (ii) selecting appropriate units for various land use types; and (iii) choosing relevant technologies. The peculiarity of the proposed 
procedure is the strong focus on considering geographical context, matter flows, neighborhoods, and dynamic processes.

\section{Landscape-Ecological Framework for Spatial Planning}

We advocate the physical-geographical viewpoint on landscape-ecological planning, since it implies careful consideration for the abiotic environment, the spatial context of any land use unit, and lateral matter flows. Contemporary physical geography, and landscape science in particular, deals with both spatial and temporal relations with a strong focus on interactions between geocomponents and spatial units $[9,10,24,27,29]$. The mandatory attributes of the approach are seen as follows:

1. Landscape maps and maps of matter flows are used as a basis for spatial referencing of land use decisions aimed at the maximum possible adaptations to natural boundaries.

2. Examination of the position and functional role of landscape units in higher-order systems is critical for making planning decisions, because certain units may contribute to the preservation of the landscape and its biological diversity more than the others.

3. The forecast of chain reactions between geocomponents (i.e., parent rocks, soil, water, air, vegetation, animals) precedes planning decisions in order to prevent irreversible man-induced loss of ecological functions.

4. Spatial decisions are adapted to lateral interactions between natural landscape units and oriented towards eliminating negative remote man-induced effects, stimulating positive ones, and minimizing the detriment to valuable natural and economic objects.

5. Optimum spatial proportions and neighborhoods of land units may generate particular interactions that produce new emergent properties of a mosaic landscape. Some of the emergent properties may be favorable for human activity and living nature, affect human health positively, and ensure the compensation of non-desirable effects of anthropogenic impact.

6. Regulation of land use in time relies on the forecast of dynamic and evolutionary changes and the assessment of landscape stability.

7. Diversity of landscape processes and multiplicity of values of geocomponents is considered to reveal opportunities for the multifunctional use of landscape units.

We propose the original framework aimed at making spatially explicit planning decisions (Figure 1). It requires the consequent answering the following questions.

1. What types of natural units constitute the landscape and how are they used nowadays? To check whether land use is adapted to an abiotic template of a landscape we apply the genetic-morphological approach to compose a landscape map and delimit units (urochishches) based on physiographic boundaries and internal spatial patterns $[9,10,30]$. We distinguish natural landscape units and anthropogenic land use units. Each natural landscape unit may be divided into several land use units, though, ideally, one-to-one correspondence is preferred. The poor correspondence between natural and land use units may be a source of serious ecological and economic problems. At the same time, similar natural units may be evaluated differently depending on the position in relation to settlements, roads, and rivers. Accessibility of a land use unit may be controlled by distances, quality of roads, and natural obstacles. Each landscape unit is involved in matter flows. Therefore, it is important to consider catchments as additional spatial units in order to analyze the influence of land use proportions on runoff and hydrochemistry. Furthermore, the structure of catena units may affect gravity-driven pathways of solid and soluble substance. Commonly, a catena unites several natural landscape units (e.g., interfluve, slope, deluvial train) linked by an unidirectional flow. To assess the landscape as an environment for migrating animals, the matrix concept of a landscape [31] is applied as well. It is helpful in the delineation of critical habitats and biocorridors within the disturbed landscape.

2. Are any changes in land use needed due to natural threats, loss of resources or land use conflicts? This item is aimed at the choice between preserving the current state of a landscape unit and choosing another land use type or another configuration of a land use unit or technology. Degradation of 
currently available resources or ecological value may be caused by inappropriate technology or undesirable matter input or output. Simultaneous use of a territory by several stakeholders may be a reason for selecting the most effective and/or environmentally friendly one.

3. What natural and social values should be taken into account before dividing the territory into the ecological network and areas for intensive land use? We consider both broad and local geographical context to decide whether a particular landscape unit has analogies and, hence, could be used for other socio-economic purposes. Geographical analysis is applied to determine whether the landscapes under consideration are rare or typical in the regional context. At the local scale we check which units within the boundaries of the landscape are unique, rare, or typical from the viewpoints of ecological and socio-economic values. The first proxy is the general rule: "Preserve rare units and concentrate anthropogenic loads within the typical and widely spread ones". The most rigid constraints are imposed by the uniqueness of a unit or a whole landscape in a regional or national context. For example, a landscape may be a World Heritage site, belong to a protected nature area, or contain unique natural resource. In the local context, the main question is whether the local community and landscape can be sustainable after a loss of values of high demand in a certain unit (e.g., recreation site, site of religious significance, hunting or gathering area, or source of drinking water). This means that the function of units in matter flows is critically important for evaluation and planning.

4. Which matter flows are ecologically important and should be protected? Which flows are undesirable and should be reduced or isolated from the ecologically-significant objects? To assess the function of landscape units in matter flows, four elements of catena [32] should be distinguished. Autonomous elements receive matter from the atmosphere only and have no connections with groundwater. Trans-eluvial elements receive matter from the upper parts of a slope and transfer it to the lower ones. Trans-accumulative elements accumulate matter from the toe slope. Super-aqual element receives matter from water streams and groundwater (e.g., on floodplains). Delimitation of the flow-based spatial units allows us to reveal sites of matter dispersion, transit, and accumulation as well as to assess flows velocity depending on relief, sediments, and possible barriers. We trace the pathways along the catenas and within the catchments and apply the rule "Avoid dispersion of harmful flows". Biotic flows are considered at this step as well, aimed at the identification of the most significant biocorridors within the disturbed section of the landscape. The key habitats and migration routes of both ecologically valuable and dangerous animals deserve careful consideration. The compatibility of anthropogenic and natural flows is a matter of crucial importance. We apply the criterion: the matter flow is treated as undesirable if it generates properties (in soils, water, plant cover, etc.) that are not inherent for the zonal background conditions. At this step, we delineate the candidate units for ecological networks where certain kinds of activity (e.g., industrial enterprises, cattle-breeding farms, or wastewater discharge) will be prohibited (e.g., along the biocorridors, in the vicinity of emergent groundwater, or in riparian zones).

5. What neighborhoods of land use units could reduce the detrimental effects of anthropogenic or natural matter flows? After identification of the main matter flows, we need to regulate pathways and velocity of undesirable flows or to eliminate them. The theory of landscape geochemistry [32,33] provides tools for identifying or projecting geochemical barriers that could intercept undesirable matter flows. The tools from the matrix concept of a landscape [31] ensure the necessary balance of connectivity and fragmentation. Socially significant neighborhoods of land use units should be revealed as well, e.g., recreation forests in the close vicinity of settlements. We use the rules "Prevent or manage undesirable flows" and "Avoid unnecessary fragmentation".

6. Do natural trends in landscape structure affect the future ecological or socio-economic significance of landscape units? Since landscape is a dynamic phenomenon, a planner should consider both internal and external drivers of changes. To get insight into future states, one needs to reveal a stage of development for each natural unit. Normally, newly emerged young units and degrading units are less stable than the mature ones. The planning decision may imply either supporting or sustaining the current tendency in a geocomponent state or in a spatial pattern (e.g., afforestation, sheet erosion, 
bogging). In some cases, the current trend forces one to reject possible decisions if a unit is unreliable in fulfilling socio-economic functions. However, a planner should consider the possibilities to resist or encourage trends by projecting particular neighborhoods or selecting appropriate technologies. The relevant rule for a planner is "Prefer stable units".

The set of planning decisions in steps 3-6 involves the delimitation of spatial units (urochishches) that contribute significantly to ecological networks and/or to intangible social values. Hence, these units require a protective regime or priority for cultural values. In terms of the ecosystem services concept [34-36], the main output of steps 3-6 is the identification and the map of units that provide regulating services and socio-cultural services. It should be noted that in many cases landscape plans should find opportunities to propose regimes that combine ecological and socio-cultural functions of ecological network. The next steps provide rationales for distributing land use activities in a landscape space outside the ecological network.

7. How should the proportions of land use types be changed to ensure the sustainable functioning of the landscape? The emergent effects may be induced by lateral interactions between contrasting landscape units, given that critical proportions and neighborhoods are provided. This is the most difficult step of planning since the theory of emergent effects is not well-developed in landscape ecology as well as an issue of critical proportions. Proportions of land use units should be projected and aimed at the imitation of natural spatial diversity. For example, runoff regime and hydrochemistry in forested regions is stable until the critical share of deforested areas is reached [37]. Timber harvesting can imitate to some extent natural disturbances, given that summary cutover area is not too large within a river basin. Moreover, the location of cutovers in the upper or lower reaches does matter either. Hence, a planner is expected to determine critical proportions before he or she will propose a concrete allocation of land use units within a basin. If the anthropogenic disturbance is critically needed, knowledge of necessary proportions provides the opportunity to select sites with proper areas for compensation measures. The matter of proportions and required diversity is critical for regulating microclimate, runoff, viability of animals populations, aesthetic values, etc. The rules applied at this step are as follows: "Ensure emergent effects by supporting necessary proportions" and "Compensate for the lost values somewhere".

8. Which land use type is the most relevant in each landscape unit? The most essential stage of landscape planning is the distribution of land use types in accordance with the internal properties of natural units and with due consideration for external effects and interactions. The most important rule in landscape planning is: "Adapt land use to natural units". Numerous studies focused on this question $[3,38,39]$. We advocate the viewpoint that this kind of decision should be made no earlier than the abovementioned steps, which take into account the hierarchical organization of landscape patterns and the functional role of each unit in matter flows. This enables a planner to evaluate the internal resources and suitability of a unit for various kinds of human activity. However, a great challenge for a planner may be in the equal suitability of a unit for various land use types [40,41]. One of the popular criteria for selecting the most suitable land use is "the least ecological evil" [5,39]. Hence, at this stage, we compare possible remote effects from land use types that have similar requirements for internal resources of a spatial unit.

9. Is it possible to suggest alternative locations for the conflicting land use type with similar requirements for the landscape conditions? To check the possibilities for possible alternative locations we compare similarity of landscape conditions, accessibility, ecological risk induced by access roads, and possible risky neighborhoods in alternative locations. The land use type with no alternative locations is preferred at the site under consideration. The relevant rule is "Compare alternative locations". 


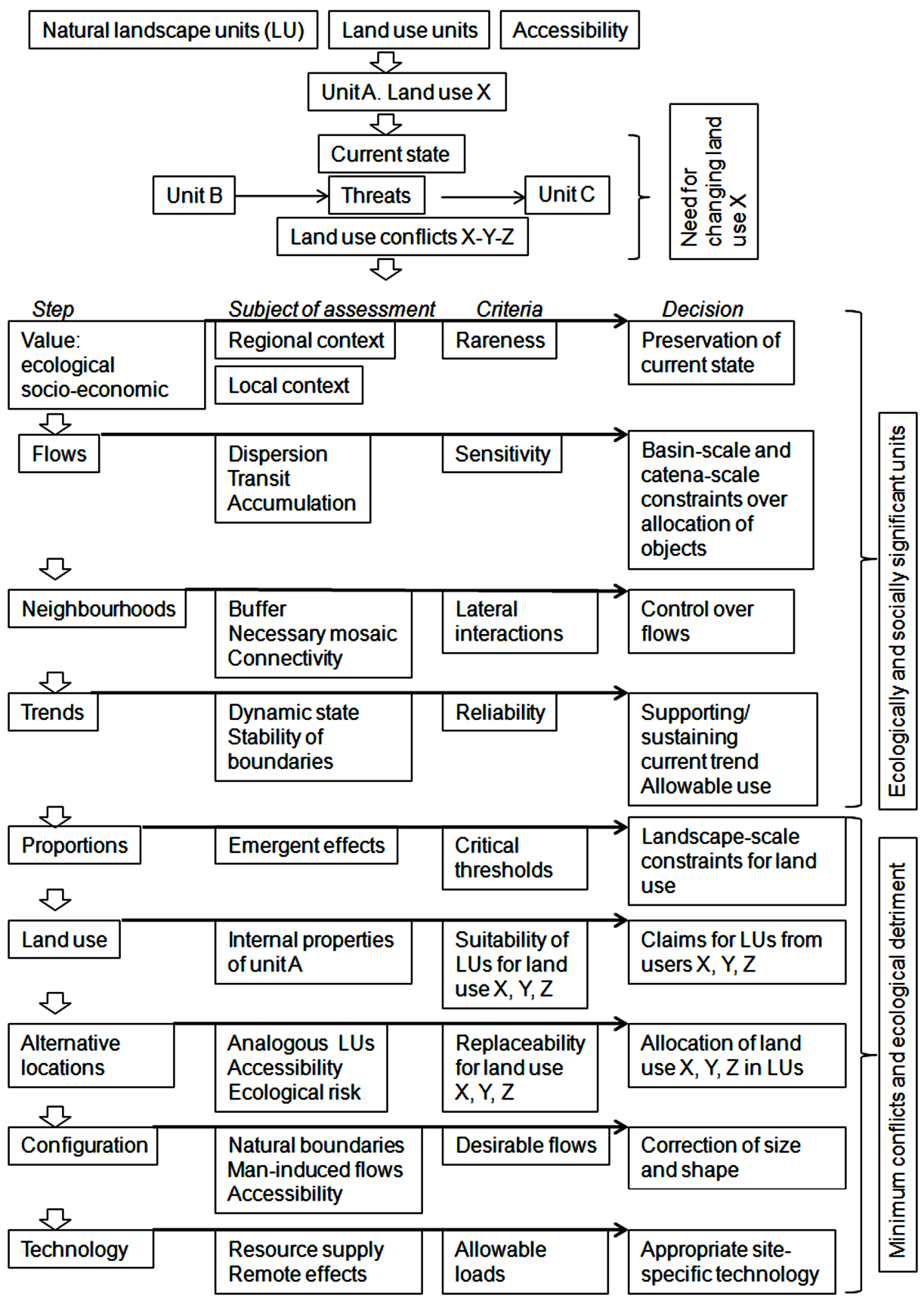

Figure 1. The framework for landscape-ecological planning. A-the focus planning unit. B and C-neighboring landscape units connected by lateral flows to A. X, Y, Z-competing land use types.

10. Which changes in land parcels configuration are needed to reduce the ecologically detrimental remote effects? Landscape planning, besides choosing correct locations, involves proposals for the appropriate shape of land use units as well. The principal requirement for configuration is the prevention of the development of undesirable matter flows as well as encouraging useful flows. The velocity of matter flows may critically depend on the available distance. For example, erosion potential depends on slope length. Since it is impossible or expensive to change slope length or gradient, the more realistic decision is to allocate a field parallel to contour lines or to provide alternation of strips with grain crops and perennial forage grass. By doing so, a planner reduces the risk that water surface flows will reach sufficient velocity for erosion. In forest regions, orientation of cutovers may ensure either better insolation or better shading, depending on geographically-specific heat or water deficits. In some cases, the proper orientation of land parcels can ensure better accessibility. 
11. Which technological improvements are needed within the established land use units? Spatial decisions, such as allocation of land parcels, projecting their proportions, and neighborhoods in a landscape, are the privilege of an integrative landscape-ecological investigation, whereas the choice of appropriate technologies is the expertise of a sectoral approach. However, at the final step, landscape ecology is expected to reduce the range of possible technological decisions. This is aimed at preventing depletion of resources by harmful chain reactions among geocomponents and/or landscape units. One can imagine, for example, that choosing the cutting season in temperate zones is critical for the preservation of the moss-and-herb layer. For this purpose, winter cutting is commonly recommended in most cases. Another important issue is adapting anthropogenic loads to landscape resilience, e.g., establishment of the allowable number of recreants in highly sensitive pine forests with lichens in plant cover or the number of grazed animals on a pasture.

\section{Study Area and Materials}

The study area comprising $152 \mathrm{~km}^{2}$ is located in northern European Russia in the middle taiga subzone (the Arkhangelsk region of Russia), in the Zayachya river basin. The highest-level landscape contrasts are determined by the combination of effects induced by: a) morainic and limnoglacial accumulation in the Riss period of the Pleistocene; b) alluvial accumulation in the valleys resulting in sand sedimentation over Permian marls; and c) erosion generating valleys and gullies and washing moraines downslope, which resulted in reduced soil thickness and local exposure of marls at the steepest slopes $[42,43]$. The forested section of the landscape is located in the upper reaches of the Zayachya basin, while the agrolandscape is located in the lower reaches (Figure 2).

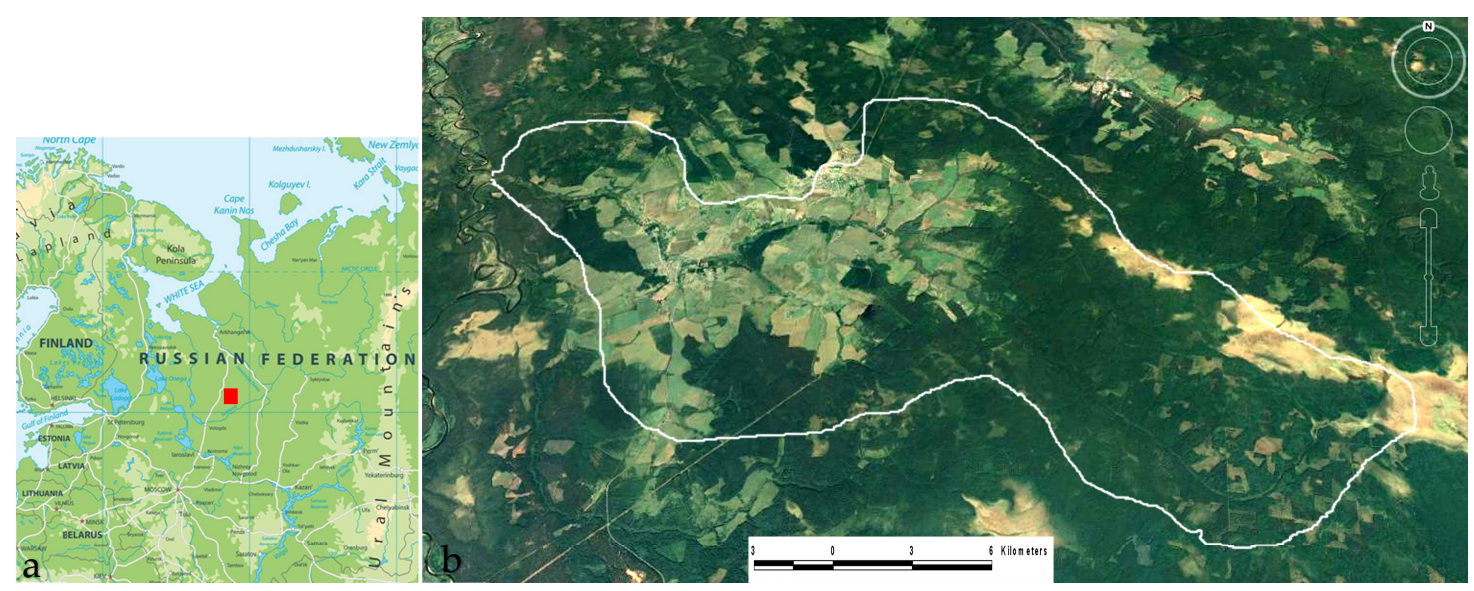

Figure 2. Study area: (a) Location of the study area in the East-European Plan, Arkhangelsk region (red rectangle); (b) The Zayachya river basin. Source: Google Earth, 2020 CNES/Airbus.

From the inner part of the interfluves towards the river valleys, Pinetum eriophoro-sphagnosum communities on Histic Gleysols or Histosols are replaced by Piceetum myrtilletosum forests on Haplic Podzols, and further by Piceetum oxalidosum forests on Umbrisols or Rhendzic Leptosols. Clear-cuttings until the 2010s were concentrated in the upper part of the Zayachya basin. Currently, only selective cuttings are allowed, and they occur much closer to the settlements in the middle part of the basin in Piceetum myrtilletosum, Piceetum oxalidosum, and Pinetum myrtilletosum forests. In secondary forests after clear-cutting, aspen (Populus tremula) dominates on the most nutrient-rich soils, birch (Betula pendula)—on soils with medium nutrients supply, and pine (Pinus sylvestris)—on the poorest soils with a thick sandy layer [43]. The agrolandscape occupies the most rugged section in the lower reaches due to fertile soils and good drainage (Figure 2). Grain crops for fodder and forage grass have priority in agriculture.

The area has been continuously used for agriculture for seven centuries. The population is totally engaged in agriculture, in timber harvesting, or in gathering. Life conditions of local people depend 
greatly on provisioning and regulating ecosystem services provided by the forested part of the basin. Berries, mushrooms, and game resources are still important sources of profit. The territory is highly contrasted in the quality and quantity of provisioning services due to the diversity of soil humidity and fertility. For the last 30 years, the area has experienced rapid changes in land use patterns caused by the transition to market economy and unstable demand for arable lands.

The field research has been continuously performed since 1994. During this period our own continuous observations and consultations with local community provided information concerning location of units with the most significant social values. We obtained information from almost 100 persons representing various social strata including several heads of local administration, agronomists, teachers, farmers, milkmaids, tractor operators, forest managers, pensioners, unemployed people, summer residents, housewives. Quarter-century long observation and communication with local people enabled us to monitor changes in land use and social demands. The initial data came from extensive field descriptions, which were performed at more than 2000 sample plots being representative of each type of urochishche. Sample plots were provided with descriptions of landforms, evaluation of species abundance and cover for all the layers of phytocoenoses, and measurements of soil properties (thickness, texture, Munsell color of horizons; exchangeable ions, $\mathrm{pH}$, humus, trace elements total content; level of soil-water). The measurements of ion contents in surface waters has been performed seasonally in 1994-2000 and since 2013 in 15 small rivers both in forested and deforested sections of the basin as well as in the Zayachya River. Previous research $[42,44]$ showed that $\mathrm{NO}_{3}{ }^{-}, \mathrm{NO}_{2}{ }^{-}, \mathrm{Mg}^{2+}, \mathrm{Cl}^{-}$, and $\mathrm{SO}_{4}{ }^{2-}$ ions and mineral and organic phosphorus were the main indicators of man-induced flows connecting anthropogenic objects or eroded soils with water bodies. Total content of $\mathrm{Mn}, \mathrm{Cu}, \mathrm{Zn}, \mathrm{Pb}$, $\mathrm{Mo}, \mathrm{Sn}, \mathrm{Ag}, \mathrm{Be}, \mathrm{W}, \mathrm{Nb}, \mathrm{V}$, and $\mathrm{B}$ in soil humus horizon and plants were determined so as to compare human-affected units with background conditions in analogous landscape units. Filipendula ulmaria was chosen as the indicator of biological accumulation of pollutants, since it is the most frequently occurring species on floodplains.

The basic units for planning decisions were taken from the original landscape map and the map of catchments. The landscape map was composed at the scale of 1:50,000 for the whole Zayachya river basin. The urochishche level was chosen for mapping, since it is the most compatible with the level of planning decisions for the local area. Each urochishche was delineated according to landforms boundaries with due consideration for plant and soil cover and their anthropogenic modifications (Question 1). State geological and geomorphological maps $(1: 50,000)$ were used to interpret the essence, morphology, and genesis of abiotic units. Delineation of plant cover units was based on Landsat 8 multi-channel image classification (k-means method) followed by field verification. ArcMap 10 and SAGA GIS were used for mapping and space image processing. For each natural unit we assessed the degree of anthropogenic transformation using the criteria of a number of affected components (Questions 1-3). The least degree of transformation with a high potential of natural recovery was assigned to the units with disturbance in vegetation only (e.g., cutting). The medium degree was assigned to the units with disturbed vegetation and soils (e.g., arable lands). The highest degree of transformation with poor ability for natural recovery was assigned to the units with disturbance of relief and deposits. Landscape units (urochishches) were used to develop proposals for the ecological network (Questions 4-7), comparison of alternatives and allocation of land use types (Questions 8-10), and choice of appropriate technologies (Question 11).

We used topographic maps $(1: 10,000)$ to reveal local variations in the structure of catenas. This issue is critical for tracing the pathways of natural and anthropogenic matter flows and predicting possible threats to ecologically valuable objects (Question 3). To assess the function of landscape units in matter flows (Question 4), we distinguished four elements of catena (sensu [32]). Autonomous elements receive matter from the atmosphere only and have no connections with groundwater. Trans-eluvial elements receive matter from upper parts of a slope and transfer it to the lower ones. Trans-accumulative elements accumulate matter at the toe slope. Super-aqual elements receive matter from water streams and groundwater (e.g., on floodplains). The landscape map was applied to identify the most important 
buffer units that could intercept pollutants migrating along the catenas and to project neighborhoods of land use units (Question 5). The landscape map was used also to identify important patches and biocorridors that serve as key elements for biotic flows (Question 5) and, therefore, should be included into the ecological network within the agrolandscape.

The landscape map was used to evaluate proportions of zonal-type (forested) and anthropogenically transformed units within each catchment. The percentages of forests and fields within a catchment were used as candidate predictors for the contents of ions in surface waters. By doing so, we tested the hypothesis that anthropogenic changes in landscape cover were responsible for deviation of hydrochemical properties from the zonal background (Question 3). Then, we evaluated the maximum allowable percentage of arable and disturbed lands that could support the background hydrochemical conditions under human impact (Question 7). The landscape map was used to choose the best locations for the land units that could ensure the ecologically safe forest/field proportions within a basin (Questions 8 and 9).

\section{Results}

The results of the study are presented below by answering subsequently the 11 questions proposed in the framework.

\subsection{What Types of Natural Units Constitute the Landscape and How Are They Used Nowadays?}

The landscape mapping resulted in the delimitation of 1617 individual natural landscape units (urochishches) (Figure 3). All the units were divided into 12 physiographic classes which were further divided into 152 types based on current vegetation, soils, and land use. For the whole legend, see [45].

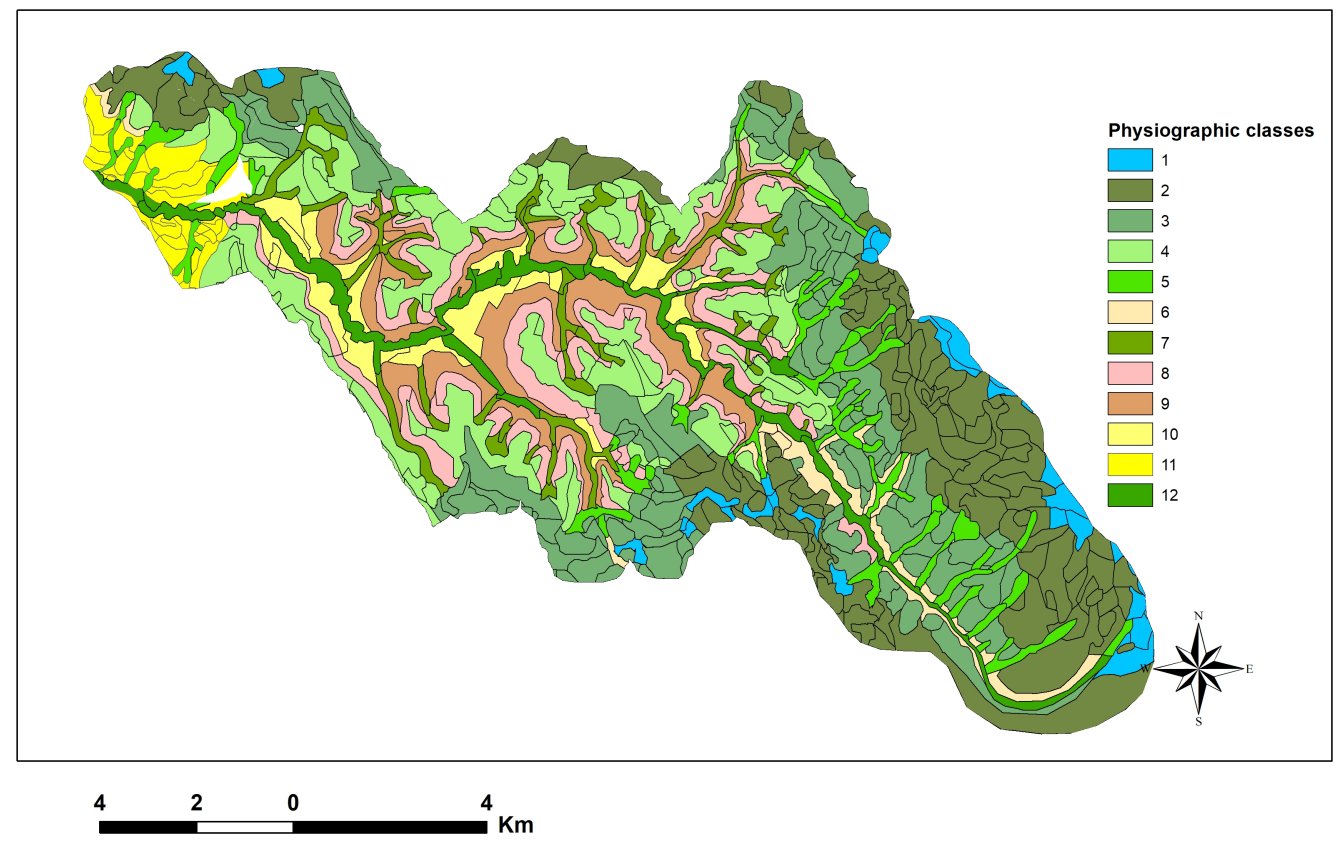

Figure 3. Landscape units in the Zayachya river basin [45]. Physiographic classes (number of urochishche types in brackets): 1-boggy depressions on interfluves (13); 2-flat poorly-drained interfluves composed of morainic loams (30); 3-slightly inclined interfluves with thin $(5-20 \mathrm{~cm})$ cover of loamy sands over morainic loams (14); 4-well-drained narrow interfluves with thick $(20-50 \mathrm{~cm})$ cover of loamy sands over morainic loams (20); 5-gullies with gentle slopes incised into morainic loams (17); 6-gentle slopes of river valleys composed of loams (7); 7-gullies and small rivers incised into marls (7); 8-steep slopes with exposure of marls (15); 9-deluvial trains (11); 10-well-drained sandy terraces (4); 11-glaciofluvial plains with aeolic landforms (18); 12-floodplains (14). 
The current land use units are shown in Figure 4. Land use pattern and recent changes demonstrate clear adaptation to sections differing in drainage conditions and soil fertility. Forests account for $65 \%$, while $35 \%$ of the basin is used for agriculture and settlements. The upper part of the Zayachya basin, with a dominance of poorly-drained and nutrient-poor landscape units, is used for timber harvesting, hunting, and gathering berries and mushrooms. Arable lands occupy the marginal parts of the interfluves and extend further to the slopes, deluvial trains and terraces. Most villages are located above the slope shoulders near the valleys. Remote fields were cultivated until the 1990s but were later abandoned due to low accessibility, poor mineral nutrition, and gleization in soils. Afforestation is typical for the abandoned fields. Grazing was practiced on the interfluves with nutrient-poor Umbri-Endogleic Albeluvisols. Since the 2010s, cattle have been kept in stables, which requires larger cultivated areas for growing forage. Therefore, some of the abandoned fields on nutrient-poor soils on terraces and interfluves have been used for cultivation again.

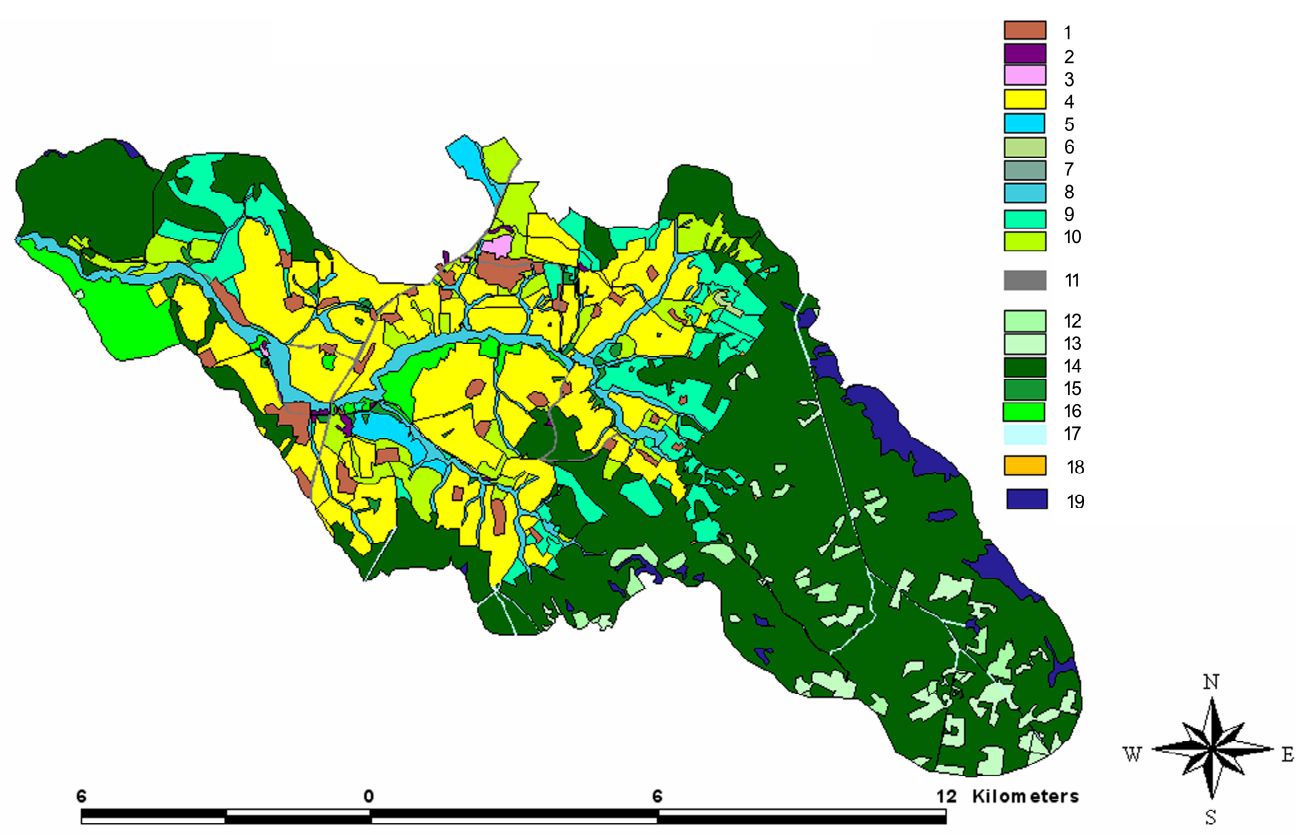

Figure 4. Land use units in the Zayachya river basin. 1-settlements, 2-industrial areas (saw-milling enterprises), 3-dairy farms, 4-arable lands, 5-pastures, 6-hayfields, 7-meadows, 8-meadows with shrubs, 9-fallows with coppice and shrubs, 10-fallows with meadows, 11-roads, 12-clear-cuttings, 13-selective cuttings, 14-forest matrix, 15-isolated forest patches, 16-socially significant forest patches, 17-glades, 18-oats fields to bait bears, 19-bogs.

\subsection{Are There Needs to Change Land Use Due to Natural Threats, Loss of Resources or Land Use Conflicts?}

The most critical challenge for land use was revealed on the plowed slopes (Figure 5). Severe sheet erosion, which has lasted for many centuries, resulted in diminished thickness of humus horizon (from 15-20 to 0-5 cm) with the subsequent exposure of non-fertile marls. The yields decreased at the slopes up to 2-3 times as compared to flat areas. Obvious remote effects were detected in trans-accumulative elements of catenas as well as in streams. Elevated contents of $\mathrm{Ca}^{2+}, \mathrm{Mg}^{2+}, \mathrm{HCO}^{-}$, $\mathrm{Cl}^{-}$, and mineral $\mathrm{P}$ in surface waters in the agrolandscape were 3-8 times as high as in the forested part of the basin. Siltation of water bodies was severe as well. This resulted in loss of water quality and decrease of fish resources. These findings indicate the necessity either for correction of land use types in adjacent catenas or for changes in the technologies, shapes, or neighborhoods of agricultural lands. 


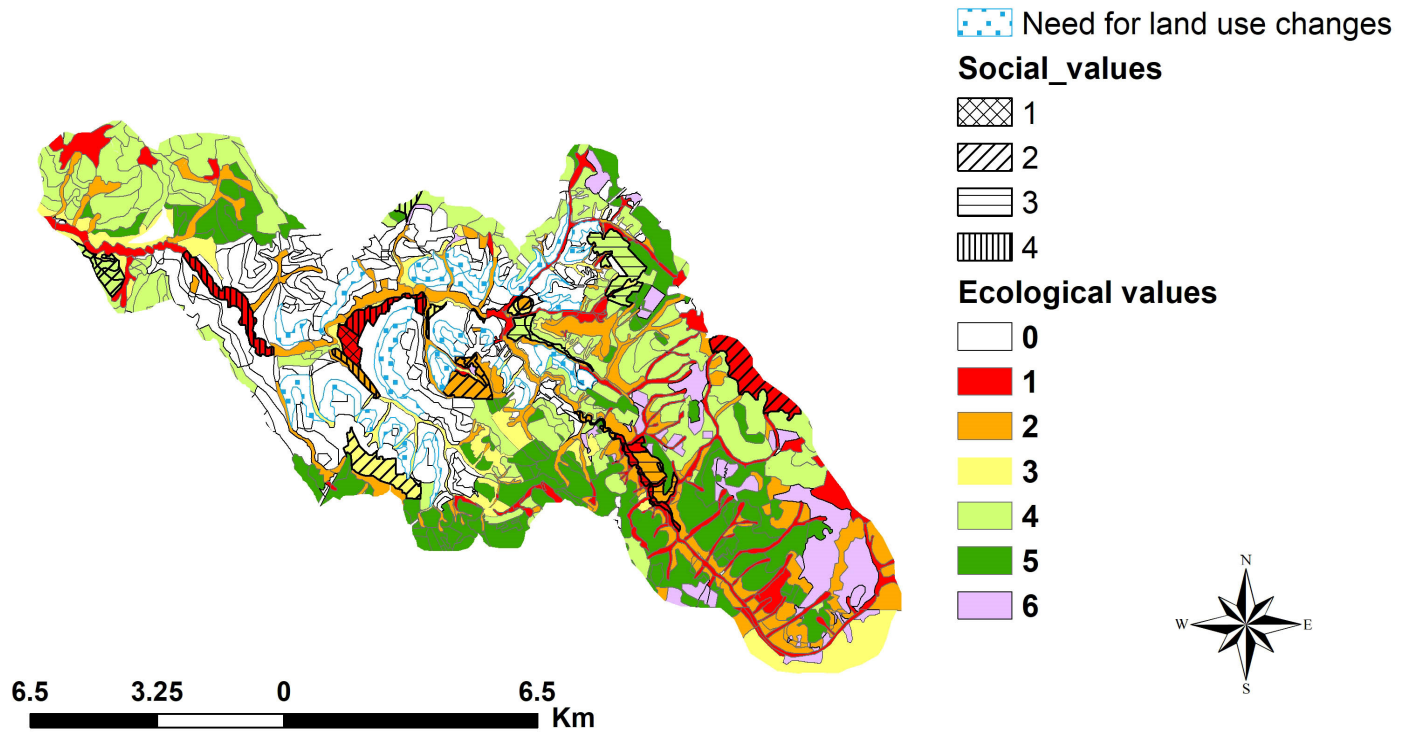

Figure 5. Needs for changes in land use, ecological and social values in the Zayachya river basin. Ecological values: 0-no ecological values; 1-high internal value (key habitats) and significant control over remote areas (biocorridor, runoff regulation, protection of rivers from siltation); 2-high internal value (key habitats, rare units); 3-buffer effects between the anthropogenically disturbed units and water bodies; 4-disturbed forest units at intermediate stages of recovery successions with a high value for feeding animals; 5-typical zonal type units with biotope functions and water-regulating capacity; 6-temporal loss of most ecological values after cutting. Social values: 1-cemetery; 2-popular areas for gathering berries and mushrooms, 3-hunting sites; 4-recreation sites.

The opposite trend in soil fertility was characteristic of the flat interfluves with gleization in soils close to the central village in the northernmost part of the territory (number 5 in Figure 4). Prolonged cattle pasturing resulted in enrichment of soils with nutrients $(\mathrm{N}, \mathrm{P})$. The recent transition to stall maintenance of the cattle provided new opportunities for plowing at former pastures aimed at the production of fodder grasses. At the same time, the construction of the new farm in the upper catchment of the small river Kameshnitsa (number 3 in Figure 4) caused strong pollution downstream. Expansion of the largest village towards the marginal section of the interfluves and a corresponding increase in the amount of communal wastes contributed to the loss of water quality as well.

Extensive cutting in the close vicinity of the oligotrophic mire in the eastern part of the territory has induced irreversible bogging with low probability of coniferous forest recovery. Hence, the long-term planning for timber harvesting may be questioned. However, hunting values may even increase in the newly-formed landscape conditions. Cutting in the close surroundings of the villages resulted in a decrease of non-timber resources, namely berries and mushrooms.

\subsection{What Natural and Social Values Should be Taken into Account before Dividing the Territory into the Ecological Network and Areas for Intensive Land Use?}

In the regional-level context, the landscape with well-drained fertile soils is unique for the southern Arkhangelsk region and is one of few of such type in the whole European taiga. Hence, a planner is expected, on the one hand, to respect the long-lasting agricultural tradition and economic significance of agriculture and, on the other hand, to minimize socio-ecological conflicts resulting from the ecologically detrimental effects of agriculture. Thus, the whole lower part of the Zayachya basin should be treated as a socio-economic regional-level value.

In the landscape-level context, the riparian forests, shrubs, and meadows on floodplains along the Zayachya River and its tributaries occupy a small area and, therefore, can be regarded as an ecologically significant rare habitats (Figure 5). Chemical and noise pollution and siltation impose constraints for the viability of animals' populations, including those connected with cultivated or 
abandoned fields by food chains (Lepus timidus, Numenius arquata). Besides that, the rare landscape units deserving protection occur on the non-cultivated steep valley slopes where exposure of marls ensures rich nutrition, high biodiversity, and abundance of nemoral flora atypical for the taiga zone. Actually, the rareness of these units is a result of cultivation aimed at the maximum possible use of fertile Rhendzic Leptosols. Isolated forest patches (up to $1 \mathrm{ha}$ ) contribute to biodiversity by creating favorable conditions for invasions of species that commonly prefer more southern habitats, such as Apodemus agrarius, Oriolus oriolus, Jynx torquilla, and Coccothraustes coccothraustes [46]. Land cultivation in the well-drained section of the landscape resulted in deforestation of sandy river terraces formerly covered by pine forests. Their remnants are now treated as rare units with rather easy accessibility and high aesthetic value. Their social significance is explained by rich resources of berries (Vaccinium vitis-idaea) and mushrooms, as well as suitability for leisure recreation in the vicinity of the river. One of these units contains the local cemetery. The abovementioned units are treated as candidates for the protective regime due to high ecological and socio-cultural values.

\subsection{Which Matter Flows are Ecologically Important and Should be Protected? Which Flows are Undesirable and Should be Reduced or Isolated from the Ecologically-Significant Objects?}

The most ecologically significant abiotic water flows in the study area connect mires and rivers. Mires are not subject to any threats nowadays. To protect the runoff volume and regime the plan implies prohibition of cutting in the lower parts of valley slopes and reduction of plowing on the steepest slopes. The valuable biotic flows of migrating animals in the agrolandscape are supported, on the one hand, by riparian vegetation along the Zayachya River, and, on the other hand, by connection of the interfluve forests with riparian forests which gradually increases due to afforestation of abandoned lands (Figure 5).

We detected the undesirable anthropogenic matter flows along the streams. The dairy farm located at the northern edge of Nagorskaya village occupies the marginal section of the flat interfluves with high soil humidity and partially the upper catchment of the Kameshnitsa River. Local drainage channels in the vicinity of the farm are connected to the upper reaches of the river. Thus, the landscape-geochemical position favors the dispersion of pollutants $\left(\mathrm{Cl}^{-}, \mathrm{SO}_{4}{ }^{2-}, \mathrm{NO}_{3}{ }^{-}, \mathrm{NO}_{2}{ }^{-}\right.$, organic $\left.\mathrm{P}\right)$ along the streams towards the Zayachya River [44]. The Kameshnitsa runs along a short ( $2.5 \mathrm{~km}-\mathrm{long})$ narrow valley with steep slopes (Figure 6, the upper left corner). In the middle reaches it receives the additional input of chemicals washed out from the fields (catena type 3, Figure 6). The water in the neighboring Smutikha River is enriched by the same ions, but the pollution is explained by the impact of sewage from private gardens on the slopes of the upper catchment and input from the fields in the lower reaches. In most cases, the chemical threat to streams is caused by the direct adjacency of trans-eluvial elements of a catena to the floodplain. Hence, the challenge to be solved by planning decisions is the better isolation of settlements and cultivated slopes from the floodplains by forest buffer strips and minimizing the chemical threat to water bodies. The functional role of slope forests may be subject to changes. For example, the pine forests in the upper reaches of the Smutikha valley lost their buffer function since cultivation of the adjacent fields stopped in early 2000 s. 

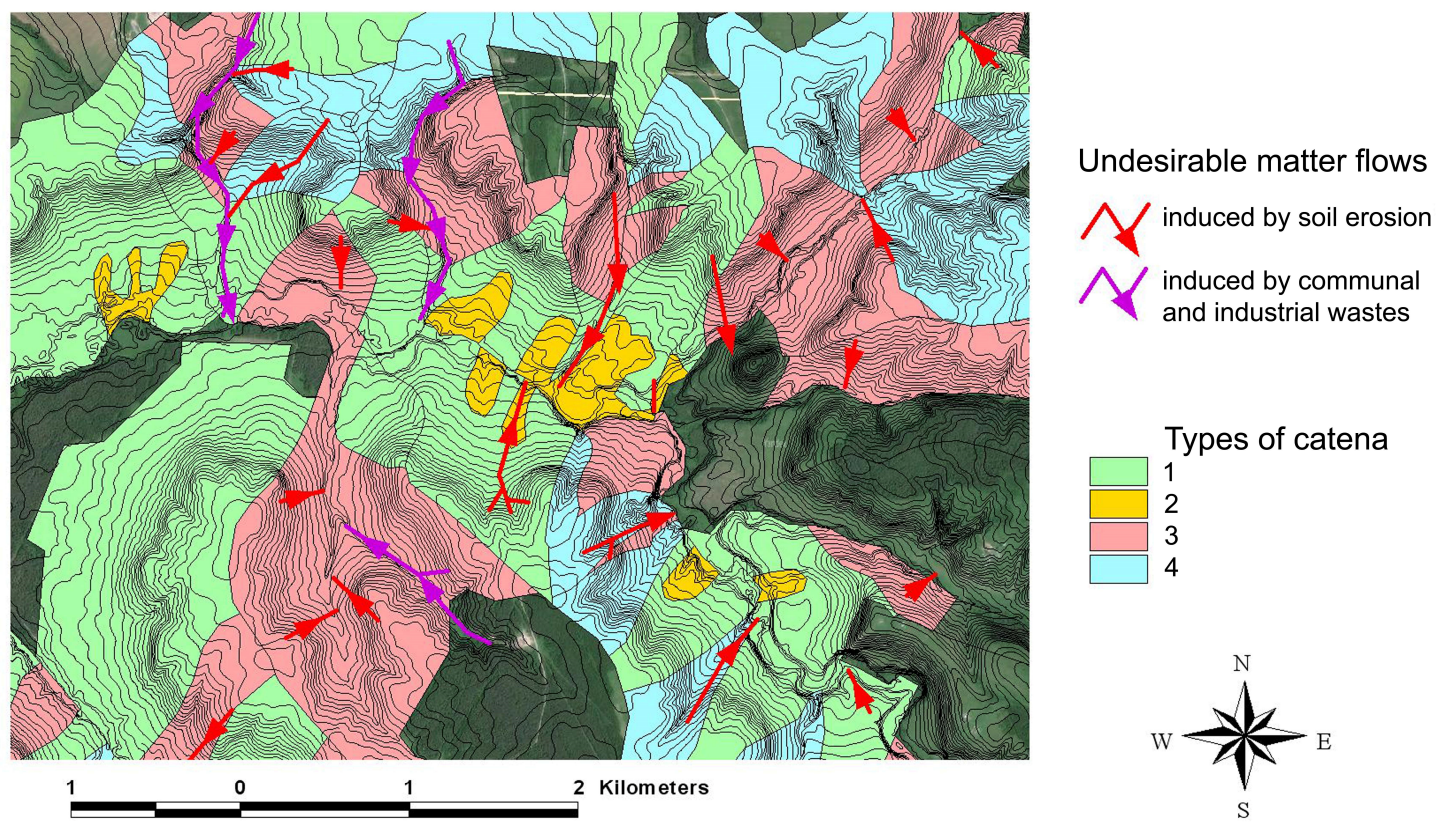

Figure 6. Pathways of undesirable matter flows and structure of catenas within the central part of the agrolandscape. Sequence of spatial elements in catenas: 1-Autonomous (interfluve)-Trans-eluvial (slope)-Trans-accumulative (deluvial train)-Autonomous (terrace)-Small gullies-Super-aqual (floodplain); 2-Autonomous (terrace)-Super-aqual; 3-Autonomous (interfluve)-Trans-eluvial-Transaccumulative-Super-aqual; 4-Autonomous (interfluve)-Trans-eluvial-Gullies-Super-aqual.

The alluvial fans in the mouths of the ephemeral courses within the agrolandscape overlay the floodplains and tend to expand due to sheet erosion in their cultivated catchments (in spring, in particular). This process results in the accumulation of chemicals washed out from the fields (catena types 2 and 3, Figure 6). We found evidence of accumulation of $\mathrm{N}, \mathrm{Ca}, \mathrm{Zn}, \mathrm{Ag}, \mathrm{Be}, \mathrm{W}$, and $\mathrm{Nb}$ in soil humus horizons. In the humus horizon $\mathrm{Li}, \mathrm{V}$, and $\mathrm{B}$ have high concentrations both in soils and in Filipendula ulmaria leaves (the leaves-soils ratios for the element contents are 6.0, 0.9, and 6.7, respectively). This testifies to the migration from cultivated fields both in immobile and dissolved forms. $\mathrm{Zn}$ has a high concentration in the floodplain soils caused by colloidal translocation. B, Li, $\mathrm{V}, \mathrm{Mo}$, and Ag accumulate in plants where alkaline groundwater emerges and delivers dissolved substance washed out from fields [42].

\subsection{What Neighbourhoods of Land Use Units Could Reduce the Detrimental Effects Anthropogenic or Natural Matter Flows?}

The measures aimed at encouraging biotic flows of zonal taiga animals involve support for the newly emerging forest biocorridor in the lower reaches of the Kozlovka and Strugnitsa rivers (Figure 5, the central sector). In other words, no special measures are needed, since the natural afforestation trend is quite positive for both ecological safety and the increase of non-timber resources. Abandonment of fields on the nutrient-poor sandy terrace and on the eroded slopes resulted in spontaneous afforestation (mainly Pinus sylvestris) during the last 20 years. This process has enhanced the connection of forests at the interfluves with riparian forests and meadows along the Zayachya River. Young pine forests on sandy terraces and deluvial trains in this section of the landscape provide new social values due to good opportunities for gathering mushrooms in summer and hunting (Scolopax rusticola, Alces alces) in autumn (Figure 5), as well as temporarily valuable habitats for birds (Buteo buteo, Circus cyaneus, Falco tinnunculus, Hippolais caligata, Phylloscopus trochilus) (pers. comm. L.G. Emelyanova).

The buffer strips with nutrient-sensitive trees and shrubs are critically needed to protect riparian ecosystems and water quality [47]. To assess the necessity for the buffer strips we analyzed the structure of the catenas (Figure 6). In the study area they are of crucial importance at the slopes of the upper 
and middle reaches of the Kameshnitsa and Smutikha Rivers suffering from the input of undesired matter from farms, settlements, and fields nearby. Of course, this kind of passive protection should be combined with measures aimed at the reduction of pollution sources. Increasing the width of unplowed strips was recommended for the distant sections of narrow plowed deluvial trains that completely overlay the terraces and directly adjust to floodplains or steep slopes eroded by rivers (Figure 6, catena types 3 and 4). This measure would favor the interception of chemicals washed out from the fields. This measure is not needed within the catenas where wide flat terraces are located between the deluvial trains and floodplain (Figure 6, catena type 1).

\subsection{Do Natural Trends in Landscape Structure Affect Future Ecological or Socio-Economic Significance of Landscape Units?}

The units experiencing an obvious trend of afforestation after abandonment are located either on the over-humidified interfluves or on the nutrient-poor sandy terraces. On the abandoned distant fields with nutrient-poor and acid Endogleyic Albeluvisols, a group of socially and ecologically valuable units has developed since the early 1990s (Figure 5, the northeastern sector). Formerly cultivated soils change their properties towards increasing thickness of humus horizons due to the development of the herbs cover. Chemical properties evolve to depletion by artificial nutrients (mobile $\mathrm{P}, \mathrm{K}$ ) and bases (exchangeable $\mathrm{Ca}, \mathrm{Mg}$ ) while contents of exchangeable $\mathrm{H}$ and $\mathrm{Al}$ rises. Gradually emerging mosaic vegetation cover with alternation of coppice (Betula pendula, Populus tremula, Salix caprea, Alnus incana), meadows, and hayfields turned out to become attractive habitats for game species (Ursus arctos, Sus scrofa, Lepus timidus, Lyrurus tetrix). Locally, the abandoned remote fields are used by hunters to cultivate oats in small patches (0.4-0.5 ha) to bait bears (Figure 5).

Thus, answering Questions 3-6 enabled us to delineate the ecological network and, by doing so, to perform a "negative selection" [48] of units that do not fulfill significant ecological functions and, hence, may be used for intensive exploitation of natural resources. The units with ecological values 1 , 2 , and 3 (Figure 5) were included in the ecological network, which accounts for approximately $10 \%$ of the area.

The main idea of the ecological network takes into account that the local economy and life conditions highly depend on the state of forests in the Zayachya basin and the river regime. The necessity to preserve the required proportion of forests as well as high biodiversity on the slopes with marls exposure was used as the rationale for the establishment of the cluster of the Ustyansky natural park [49]. The project proposals were prepared in 2019 by a team of World Wildlife Fund experts, including the author, and currently are at the stage of discussion and approval by local administrations and stakeholders. The core of the cluster involves the continuous forest areas from the bogged central interfluves to the non-fragmented forest expanse intruding into the agrolandscape. This part of the forest matrix will be in good connection with the valuable riparian units among the cultivated areas. The proposed regime implies prohibition of clear-cutting, local permission of selective cutting and hunting, and permission for the traditional exploitation of non-timber resources in concordance with legislation. Several types of forest patches (Figure 5, ecological values 1 and 2) deserve establishment of the regime of "specially protected forest patches", which is the category of protection according to the Forest Code of Russia. The most important units in this list include: a) eutropic and mesotrophic mires with high biodiversity at the floodplains, in the vicinity of the tributaries' mouths in particular (Figure 5, ecological value 1); b) riparian forests along the rivers populated by beavers (Castor fiber) locally connected by continuous forest strips or coppice with the forested interfluves and bogs (Figure 5, ecological value 2); c) forests protecting the river banks from pollution and excessive man-induced erosion (Figure 5, ecological value 3); d) forests in water-protection zones (up to $50 \mathrm{~m}$ wide along each bank) (Figure 5, ecological value 3); e) small forest biotopes among the arable lands (Figure 5, ecological value 1); and f) socially significant forests adjusting to the settlements (Figure 5, social values 1-4). 
4.7. How Should the Proportions of Land Use Types be Changed to Ensure Sustainable Functioning of the Landscape?

Since the land use proportions are critically important for the sustainable functioning of river basins, we developed a set of measures adapted to the local peculiarities of the catchments (Figure 7). The proposals are aimed at managing proportions of forested and non-forested lands with due regard to the existing and desired spatial patterns. The proportion of forests in the upper section of the Zayachya river basin accounts for $65 \%$ of the area. This seems to be a rather high figure if a planner does not pay attention to the quality of the forest cover and its influence on runoff. The natural trend for recovery of cutover areas of the 1970-1980s is, in general, favorable for the improvement of the runoff regime. However, a high proportion of young small-leaved forests (Betula pendula, Populus tremula) causes elevated transpiration and decreased runoff volume, which will last at least for 10-20 years until the age of the stands will exceed 50 years. Taking this fact into account, the selective cuttings practiced now in mature stands encourage surface runoff, on gentle slopes in particular.

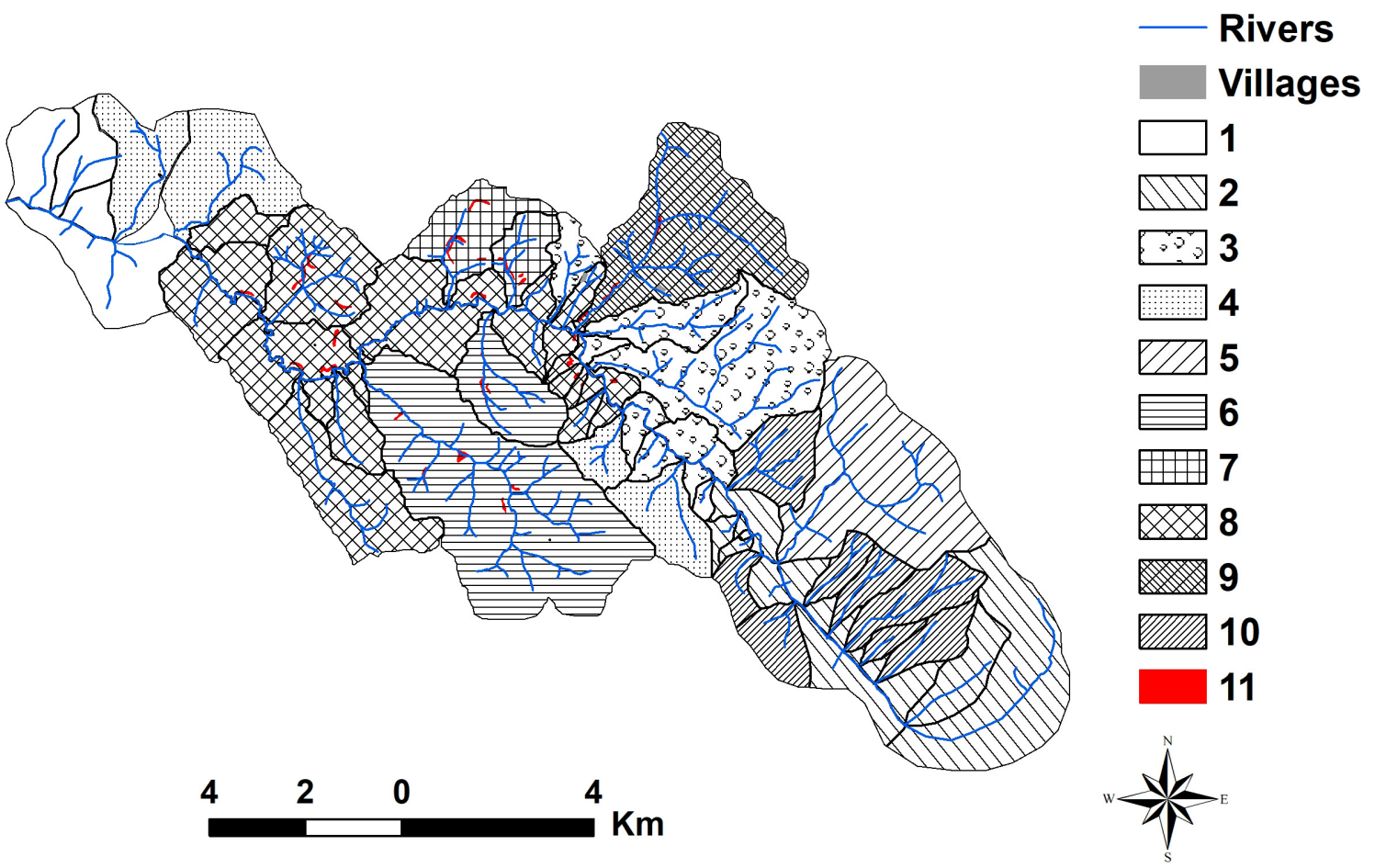

Figure 7. Planning decisions at the catchment level. 1-no special measures needed, 2-limitations for clear-cuttings aimed at preservation of forests share and spatial mosaics; 3-support for spontaneous afforestation, 4-preservation of forests in the upper catchments; 5 -regulated cuttings aimed at increase of surface runoff; 6-reduction of plowing on steep slopes; 7-creation of forest buffer strips aimed at the protection from communal wastes; 8-expansion of forest buffer strips aimed at the protection from siltation and agricultural pollution; 9-afforestation on steep slopes instead of plowing; 10-selective cutting and prohibition of clear-cutting aimed at minimizing surface runoff; 11-proposed forested buffer strips.

The current proportion of forests and fields in most small basins favors undesirable trends in hydrological and hydrochemical properties of the rivers [44]. In wet years during the vegetation period the higher forest cover (over 30\%) results in a decrease of runoff modulus. The variability of runoff modulus is inversely related to the proportion of arable lands (Spearman's $r=-0.53$ ). The share of arable lands over $60 \%$ contributes to strong sheet erosion, which results in input of $\mathrm{Ca}^{2+}, \mathrm{Mg}^{2+}$, $\mathrm{HCO}_{3}{ }^{-}$, mineral $\mathrm{P}$, and $\mathrm{NO}_{3}{ }^{-}$during snowmelt. The hydrochemical investigation showed evidence that the proportion of arable lands within a basin is directly related to the content of $\mathrm{Ca}^{2+}, \mathrm{Mg}^{2+}, \mathrm{NO}_{3}{ }^{-}$, 
and mineral $P$ in surface waters [44]. To avoid the critical transformation of the zonal ion ratios, it was recommended that the proportion of arable lands in a small river basin should not exceed $65 \%$. The preferred landscape units for increasing forested areas are steep valley slopes with gradients over $5^{\circ}$, gullies, and distal sectors of narrow deluvial trains adjacent directly to floodplains (Figure 6, catena type 3).

\subsection{Which Land Use Type is the Most Relevant in Each Landscape Unit?}

In the study area, the distribution of agriculture and forestry rather strictly follows high-order landscape boundaries that separate poorly-drained and well-drained sectors corresponding to mesochores [50] or mestnost (sensu [9]). However, the lower-level contrasts are often ignored because of the economic inefficiency of cultivating small parcels. The usual problem in agriculture and forestry is the discrepancy between the expected yields that were calculated from the known area and the real productivity that varies in accordance to natural heterogeneity.

From the explanations above, it follows that the functional zoning of the landscape should be corrected (Figure 8). The traditional timber-harvesting functional zone in the upper reaches should be diversified and aimed at the delimitation of protective zones on the slopes that contribute much to the regulation of surface flows and the preservation of key habitats. The permitted selective cutting should be distributed relatively uniformly in space in order to avoid strong fragmentation of forest habitats and to preserve the most easily accessible resources of berries and mushrooms in the vicinity of the villages.

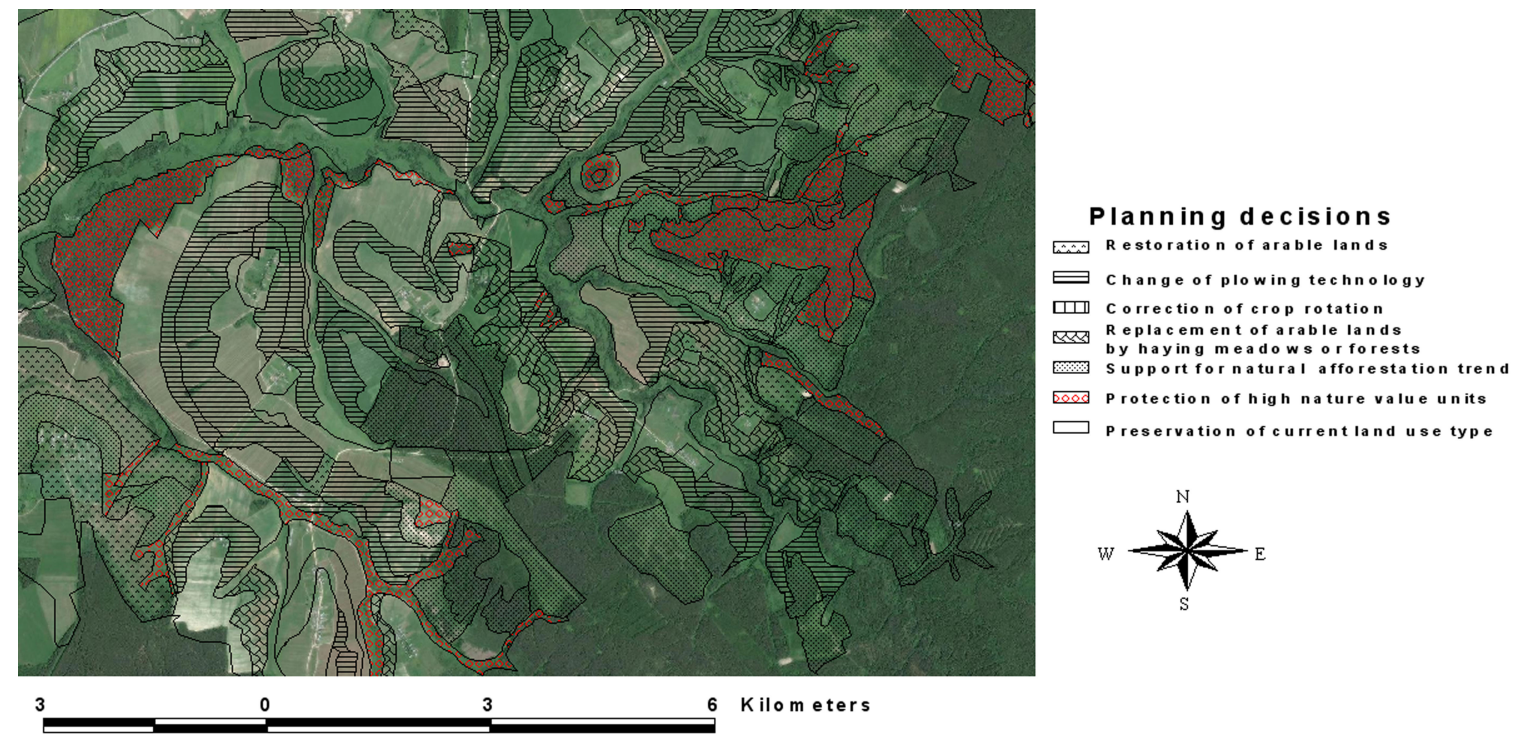

Figure 8. The proposals for landscape planning decisions within the agrolandscape.

In the forested upper part of the Zayachya basin the selective cutting, which is now allowed in the protected forests, ensure long-term reliability of timber and non-timber resources. The current climate trend improves the conditions for natural regeneration, which are especially favorable at narrow cutovers $20-40 \mathrm{~m}$ wide. The recreation value of the pine stands on the well-drained sandy terraces and interfluves should be preserved carefully (Figure 5, social value 4). However, in this case, the selective cuttings should not be concentrated in the close vicinity of the villages up to the distance of $1 \mathrm{~km}$ from the forest edge. At the same time, resistance of such stands to fires is expected to decrease under rising summer temperatures and less summer precipitation. This necessitates enhancing the firefighting measures and restricting recreation in pine forests during the long dry periods in summer.

The marginal easternmost part of the agrolandscape, where wet poor soils on flat surfaces dominate, is now abandoned. However, it is now suitable for hunting and exploiting non-timber 
resources due to the early stages of afforestation. The agricultural zone in the rugged terrain according to the planning proposal needs changes in configuration though preserving the same area. The slope units that have almost lost their soil quality due to sheet erosion and now contribute to water pollution are preferable for reforestation or establishment of hayfields. The distal sections of the deluvial trains are relevant candidates for the inclusion into the ecological network as buffer strips to protect floodplain habitats and surface waters from pollution (Figure 7). The former pastures and fallows on flat surfaces could be partially converted into arable lands to compensate for their loss on slopes.

The existing road network does not meet the requirements for accessibility of the arable lands needed to supply the cattle kept in stables with forage. Repeated cultivation of fields in the vicinity of Nagorskaya and in some terraces is encouraged by rather easy access. However, cultivation of the analogous remote fields in the eastern part of the agrolandscape is restrained by the low quality of unpaved roads. The access to the distant fields can be ensured by building roads along the steep valley slopes. Reconstruction of existing unpaved roads will enhance the risk of erosion, which is quite typical now and forces the drivers to look for alternative parallel routes using adjacent fields or meadows. Construction of paved roads requires much more excavations and earthwork with a possible short-term detriment to the linear elements of the ecological network in the valleys. However, this should be considered as "the least evil" in comparison with unpaved roads. At any rate, even provided that the paved roads are constructed, the transport expenses of cultivating the remote fields will be much higher than the analogous nearest ones. These fields are non-optimum locations and need great input of fertilizers. Therefore, the planning alternative could be aimed at reducing the frequency of plowing by the allocation of either crop rotation with maximum duration of perennials cultivation or natural hayfields. The other option is to create multifunctional mosaic units with an alternation of coppice and small hayfields that could meet the requirements of both hunting and agriculture. Other options are to use non-optimum remote fields for building recreation infrastructure using the close neighborhood of forests with rich non-timber resources or to place saw-milling enterprises.

\subsection{Is It Possible to Suggest Alternative Locations for the Conflicting Land Use Type with Similar Requirements for the Landscape Conditions?}

Landscape units with well-drained flat surfaces comply with the requirements of various stakeholders. On the Zayachya terraces the relief is suitable for agriculture, construction building, and recreation facilities. On the other hand, the fertility of sandy soils in some terrace units is low. Therefore, the terraces are seen as a spatial reserve for the expansion of several villages with good road access, construction of the saw-milling enterprise, and allocation of dumps. All of the aforementioned activities, and the latter one in particular, have strong ecological limitations for neighborhoods, since they generate a risk for water via infiltration of pollutants to groundwater and the small distance to the rivers.

Since the most severe limitations for agriculture were revealed on steep slopes, it was crucially important to find relevant alternatives. Some of the recently abandoned deluvial trains and terraces may compensate for the proposed termination of plowing slopes.

\subsection{Which Changes in Land Parcels Configuration are Needed to Reduce the Ecologically Detrimental Remote Effects?}

In the agrolandscape, sheet erosion could be reduced by plowing parallel to contour lines (Figure 8). The other, more effective, option is switching the land use type on steep slopes from plowing to haying. This could be complemented by changing the plowing direction on terraces and deluvial trains to one that is parallel to the floodplain. The latter could provide the opportunity to preserve the technologically required length of fields so as to avoid an undesirable increase of fuel consumption.

In the upper reaches of the basin, the width of cutovers should not exceed 1-2 tree heights (30-50 $\mathrm{m})$ to support runoff-regulating functions of the slope forests. This measure would encourage seed 
dispersal and quicker forest recovery. Orientation along the contour lines is recommended to avoid soil erosion.

On the terraces selected for construction building it is necessary to avoid shrinkage of pine forests that have high potential for recreation. The objects, if possible, should be oriented perpendicular to a river to minimize possible pollution of groundwater and surface water. The widest possible undeveloped strip between the object and floodplain is needed to maximize distance to the river for groundwater that could be polluted.

While constructing unpaved roads, it is crucially important to avoid gullies in order to prevent an increase of pollution and siltation. On the floodplains, minimizing the disturbed area and intersections of roads would preserve the maximum possible areas of valuable riparian elements of the ecological network.

\subsection{Which Technological Improvements are Needed within the Established Land Use Units?}

The following set of technological measures will be helpful in ensuring ecologically safe development of the territory.

In the forested section of the basin, winter cutting is preferable to preserve plant and soil cover as much as possible, on slopes and in over-humidified sites in particular. In the agrolandcape, row crops should be excluded on the plowed slopes to reduce soil erosion. Road construction, while intersecting floodplains, should be aimed at minimizing the disturbed area. Gentle-sloped ditches along the unpaved roads on slopes would allow avoiding road erosion and preventing the spontaneous expansion of a road. Construction work during the wet period should be prohibited. The chemical threat to the right tributaries of the Zayachya requires a radical reconstruction of the sewerage aimed at avoiding any contact of sewage water with surface runoff.

\section{Discussion}

The main purpose of landscape-ecological planning is to adapt land use decisions to the natural landscape structure with due consideration of the abiotic template. This implies that the better land use units correspond to natural boundaries and properties of natural units, the less ecological detriments will occur. If the size and shape of land use units imitate natural disturbances (e.g., windfalls), the emerging matter flows, both biotic and abiotic, will not exceed the range inherent for the landscape. From the viewpoint of economic benefits, the proposed adaptation of land use units to natural boundaries ensures the uniformity of production conditions.

The need for elaborating the new framework for spatial planning was dictated, on the one hand, by the lack of practice of integrative ecologically oriented planning in Russia, and, on the other hand, by the absence of legal regulations for landscape-ecological planning. Sectoral planning still strongly prevails in Russia. Each sector of the economy tries to maximize its own interests, in most cases at the expense of the other sectors or ecological values.

Since the 1990s, strong efforts were made in several post-Soviet countries (Russia, Ukraine, Armenia, Azerbaijan, and Georgia) to adapt the German-born methodology [3,51] to national realities [52,53]. This methodology is based on the overlay of significance and sensitivity values obtained separately for biotopes, soils, water, etc. To some extent, the methodology follows the tradition dating back to the works by Elliot, McHarg, and Dorney [6,38]. The successful landscape plans were elaborated in several regions (the Baikal, Altay, Kaliningrad, Yaroslavl regions, etc.) with the support of regional authorities.

In our opinion, the obvious advantages and successful implementation of this methodology do not exclude some significant shortcomings that we tried to avoid in the proposed framework. We believe that separate assessments for the geocomponents (vegetation, soils, water, etc.) may lead to significant mistakes, since many ecological values emerge as a result of between-geocomponents interactions. For example, the significance of a buffer forest strip on the slope cannot be related to vegetation only. The ability of plants to absorb pollutants must be attributed to soil properties as well, since the mobility of dissolved substances highly depend on geochemical conditions, soil texture, and slope gradient. 
Hence, a landscape unit as a whole is a more appropriate object of planning than geocomponents per se. Moreover, the methodology commonly applied in Russia underestimates the values that emerge in a broad spatial context and/or as a result of lateral flows. It is insufficient to evaluate biotopes based on the relic and endemic features while ignoring their involvement in migration corridors. In addition to the cited methodology, we propose a number of tools aimed at understanding the contribution of landscape units to the regulation of lateral abiotic flows. Finally, our framework pays much more attention to important planning tools, such as projecting relevant spatial proportions, configurations, and neighborhoods of land use units using both physiographic and flow-based spatial units. In our opinion, the most recent landscape planning methodologies (e.g., [5]) pay insufficient attention to these issues.

Contemporary methodologies of landscape planning recognize that all the spatial units are involved into lateral interactions by means of matter and energy flows. The framework proposed in this paper develops the idea that the location's priority is based not only on its own characteristics but on those of other locations as well [54]. Spatial context provides rationales for evaluation of rareness vs. typicality of landscapes, their socio-economic and ecological values [55]. We believe that the multi-scale viewpoint on this issue is needed. That is why we tries to enrich the planning approach by the sequence of steps aimed at revealing values in regional, landscape, basin, and catena scale. Source-pathway-receptor paradigm implies that management of water resources has to involve identifying the origin of water pollution (source), determining the method of action to transport the pollutant from source to the waterbody (pathway), and understanding the impact upon water quality of the pollutant once it has entered the waterbody (receptor) [56]. In this chain, in our opinion structure of a catena, determined by topography, is a particularly important criterion that should be taken into consideration. The necessity and efficiency of buffer zones, which are commonly projected as strips of permanent vegetation grown [57], depend greatly on relief peculiarities. This is the reason why we believe that catena classification should be a necessary step in landscape planning.

The critical challenge and, at the same time, opportunities for implementation of the proposed framework lie in gaps in Russian planning legislation. Some of the tools are aimed at application of spatial decisions that ensure the preservation of ecological values that cannot be legally regulated. For example, the width of water-protecting strips with severe limitations for land use, according to the Water Code of Russia, may range between 50 and $200 \mathrm{~m}$ depending on the river length despite the real structure of floodplains and valley slopes. We propose a way to allocate land use units that ensures the protection of riparian ecosystems outside the legal water-protecting stip. The Forest Code allows the establishment of "specially protected forests" for rare habitats and erosion-endangered slopes but omits the necessity to establish a particular regime for the significant biocorridors. The legislation for territorial planning still does not include the notion of ecological network, though in reality this idea can be realized via various legal opportunities (nature protected areas, water-protecting strips, protective forests, etc.). Our framework for landscape-ecological planning implies a number of instruments that provide opportunities to adapt land use regimes and spatial parameters of land use units to the requirements of ecological safety even if the legal opportunities are lacking. Most of the recommended technological improvements are aimed at minimizing undesirable matter flows that could affect soils and surface waters in the conditions of abundant humidity and dissected relief. In other words, technologies are expected to reduce unnatural remote lateral interactions between landscape units.

\section{Conclusions}

Our research showed that a landscape-ecological approach to spatial planning requires the simultaneous and coordinated application of several models of spatial organization of nature. The concrete land use decisions were made at the level of relatively uniform landscape units considering their intrinsic properties, but within the framework conditions imposed by higher-level geosystems. The structure of catena dictates the decisions concerning regulation of matter flows and protection of the vulnerable units from the undesirable unidirectional flows. Basins as the higher order flow-based 
units impose constraints concerning proportions of land use units and the desired emergent effects for runoff resulting from their lateral interactions. Landscape-level analysis based on stable abiotic heterogeneity provides rationales for adjusting land cover proportions to the needs of both man and nature, and migrating animals in particular. Finally, the highest-order constraints that affect unit-level decisions are imposed by the degree or rareness or even uniqueness in the regional or national context. Obviously, similar units may be subject to different evaluation depending on the region-specific values. In the study area, the necessity to support agriculture in the taiga zone follows from the uniqueness of well-drained landscapes with fertile soils for the region. On the other hand, high economic value has forced concentrated and heavy anthropogenic loads on a limited area. As a result, the landscape experienced a considerable increase in the intensity of lateral matter flows that reduce both the economic value of certain units and the ecological value of highly sensitive riparian ecosystems. Thus, we conclude that excessive concentration of anthropogenic loads in the unique landscape induces a negative feedback: the heavier the loads, the smaller the economic opportunities that the landscape can provide. In these conditions, the landscape-adaptive spatial organization of land use may serve as a proper solution for the problem.

To ensure the landscape-adaptive spatial organization of land use, we performed the procedure based on understanding the hierarchical and multi-pattern organization of nature. First, we established the ecological network, which protects critical habitats, sustains the critically important matter flows, provides buffer strips between anthropogenic threats and sensitive ecosystems, and ensures the sustainability of exploited natural resources. After that, we established the ecologically effective proportions of land use units (forests and arable lands, in particular). We then proposed the distribution of land use units adapted to the heterogeneity of natural conditions and economic requirements. Finally, the relevant technological improvements were recommended within the established land parcels.

Funding: This research was funded by the Russian Foundation for Basic Research, grant number 20-05-00464.

Acknowledgments: The author is grateful to Lyudmila Emelyanova for the valuable consultations concerning habitats of animals and to Anna Lukyanova for the chemical analysis of water.

Conflicts of Interest: The author declares no conflict of interest.

\section{References}

1. Bettinger, P.; Lennette, M.; Johnson, K.N.; Spies, T.A. A hierarchical spatial framework for forest landscape planning. Ecol. Model. 2005, 182, 25-48. [CrossRef]

2. Ahern, J. Theories, methods and strategies for sustainable landscape planning. In From Landscape Research to Landscape Planning: Aspects of Integration, Education and Application; Tress, B., Tress, G., Fry, G., Opdam, P., Eds.; Springer: Dordrecht, The Netherlands, 2006; pp. 119-131.

3. von Haaren, C.; Galler, C.; Ott, S. Landscape Planning. In the Basis of Sustainable Landscape Development; Gebr. Kindenberg Buchkunst: Leipzig, Germany, 2008.

4. Özyavuz, M. Landscape Planning; Özyavuz, M., Ed.; InTech: Rijeka, Croatia, 2012. [CrossRef]

5. Mikloš, L.; Špinerova, A. Landscape-Ecological Planning LANDEP; Springer: Cham, Switzerland, 2019.

6. Ndubisi, F. Ecological Planning: A Historical and Comparative Synthesis; John Hopkins University: Baltimore, MD, USA, 2002.

7. Antrop, M.; van Eetvelde, V. Landscape Perspectives. In The Holistic Nature of Landscape; Springer: Dordrecht, The Netherlands, 2017.

8. Carlsson, J.; Lidestav, G.; Bjärstig, T.; Svensson, J.; Nordström, E.-M. Opportunities for Integrated Landscape Planning-The Broker, the Arena, the Tool. Landsc. Online 2017, 55, 1-20. [CrossRef]

9. Solnetsev, N.A. The natural geographic landscape and some of its general rules. In Foundation Papers in Landscape Ecology; Wiens, J.A., Moss, M., Turner, M.G., Mladenoff, D.J., Eds.; Columbia University Press: New York, NY, USA, 2006; pp. 19-27.

10. Dyakonov, K.N.; Kasimov, N.S.; Khoroshev, A.V.; Kushlin, A.V. Landscape Analysis for Sustainable Development. Theory and Applications of Landscape Science in Russia; Dyakonov, K.N., Kasimov, N.S., Khoroshev, A.V., Kushlin, A.V., Eds.; Alex Publishers: Moscow, Russia, 2007. 
11. Neef, E. Die Theoretischen Grundlagen der Landschaftslehre; Gotha-Leipzig: Haack, Germany, 1967.

12. Christian, C.S.; Stewart, G.A. Methodology of integrated survey. In the Conference on Aerial Surveys and Integrated Studies; UNESCO: Tolouse, France, 1968; pp. 233-280.

13. Khoroshev, A.; Koshcheeva, A. Landscape ecological approach to hierarchical spatial planning. Terra Spectra Plan. Stud. 2009, 1, 3-11.

14. Von Haaren, C.; Lovett, A.A.; Albert, C. Theories and Methods for Ecosystem Services Assessment in Landscape Planning; von Haaren, C., Lovett, A.A., Albert, C., Eds.; Springer: Dordrecht, The Netherlands, 2019.

15. Van Der Sluis, T.; Pedroli, B.; Frederiksen, P.; Kristensen, S.; Busck, A.G.; Pavlis, V.; Cosor, G.L. The impact of European landscape transitions on the provision of landscape services: An explorative study using six cases of rural land change. Landsc. Ecol. 2018, 34, 307-323. [CrossRef]

16. Selman, P. Planning at the Landscape Scale; Routledge: London, UK; New York, NY, USA, 2006.

17. Van Berkel, D.; Verburg, P.H. Combining exploratory scenarios and participatory backcasting: Using an agent-Based model in participatory policy design for a multi-functional landscape. Landsc. Ecol. 2012, 27, 641-658. [CrossRef] [PubMed]

18. Steiner, D.F. The Living Landscape. An Ecological Approach to Landscape Planning; Island Press: Washington, DC, USA; Covelo, CA, USA; London, UK, 2008.

19. Brady, M.; Sahrbacher, C.; Kellermann, K.; Happe, K. An agent-based approach to modeling impacts of agricultural policy on land use, biodiversity and ecosystem services. Landsc. Ecol. 2012, 27, 1363-1381. [CrossRef]

20. Schaller, N.; Lazrak, E.G.; Martin, P.; Mari, J.-F.; Aubry, C.; Benoît, M. Combining farmers' decision rules and landscape stochastic regularities for landscape modelling. Landsc. Ecol. 2011, 27, 433-446. [CrossRef]

21. Chow, T.E.; Sadler, R. The consensus of local stakeholders and outside experts in suitability modeling for future camp development. Landsc. Urban Plan. 2010, 94, 9-19. [CrossRef]

22. Trovato, M.G.; Ali, D. Planning tools for the protection of the natural and cultural heritage in the Eastern Mediterranean area. In Innovations in Landscape Research; Mueller, L., Eulenstein, F., Eds.; Springer: Cham, Switzerland, 2019; pp. 467-486.

23. Centre for Landscape Research, University of Roskilde. Multifunctional Landscapes; Brandt, J., Tress, B., Tress, G., Eds.; Centre for Landscape Research, Roskilde University: Roskilde, Denmark, 2000.

24. Krőnert, R.; Steinhardt, U.; Volk, M. Landscape Balance and Landscape Assessment; Krőnert, R., Steinhardt, U., Volk, M., Eds.; Springer: Berlin/Heidelberg, Germany, 2001. [CrossRef]

25. Haber, W. Grundziige einerokologischen Theorie der Landnutzungsplanung. Innere Kolonisation 1972, 21, 294-299.

26. Brandt, J.; Vejre, H. Multifunctional Landscapes. Theory, Values and History; Advances in Ecological Sciences; WIT Press: Southampton, UK, 2004; Volume 1, pp. 1369-8273.

27. Angelstam, P.; Grodzynskyi, M.; Andersson, K.; Axelsson, R.; Elbakidze, M.; Khoroshev, A.; Kruhlov, I.; Naumov, V. Measurement, Collaborative Learning and Research for Sustainable Use of Ecosystem Services: Landscape Concepts and Europe as Laboratory. Ambio 2013, 42, 129-145. [CrossRef] [PubMed]

28. Angelstam, P.; Elbakidze, M.; Axelsson, R.; Khoroshev, A.; Pedroli, B.; Tysiachniouk, M.S.; Zabubenin, E. Model forests in Russia as landscape approach: Demonstration projects or initiatives for learning towards sustainable forest management? For. Policy Econ. 2019, 101, 96-110. [CrossRef]

29. Christopherson, R.W. Geosystems: An Introduction to Physical Geography, 9th ed.; Prentice Hall: Upper Saddle River, NJ, USA, 2014.

30. Khoroshev, A.V. Concepts of landscape pattern. In Landscape Patterns in a Range of Spatio-Temporal Scales; Khoroshev, A.V., Dyakonov, K.N., Eds.; Springer Nature AG: Cham, Switzerland, 2020; pp. 3-18.

31. Forman, R.T.T.; Godron, M. Landscape Ecology; Wiley: New York, NY, USA, 1986.

32. Perelman, A.I. Landscape Geochemistry; Translated from Russian; Vysshaya Shkola: Moscow, Russia, 1972.

33. Fortescue, J.A. Landscape geochemistry: Retrospect and prospect-1990. Appl. Geochem. 1992, 7, 1-53. [CrossRef]

34. de Groot, R.S. Functions of Nature. Evaluation of Nature in Environmental Planning, Management and Decision Making; Wolters-Noorfholf: Groningen, The Netherlands, 1992; p. 315.

35. Grünewald, K.; Bastian, O. Ecosystem Services-Concept, Methods and Case Studies; Grünewald, K., Bastian, O., Eds.; Springer: Berlin/Heidelberg, Germany, 2015.

36. Burkhard, B.; Maes, J. (Eds.) Mapping Ecosystem Services; Pensoft Publishers: Sofia, Bulgaria, 2017; p. 374. 
37. Likens, G.E.; Bormann, F.H. Biogeochemistry of a Forested Ecosystem; Springer: New York, NY, USA, 1995; p. 159.

38. McHarg, J. Design with Nature; Natural History Press: Garden, NY, USA, 1969.

39. Ružička, M.; Mikloš, L. Landscape-Ecological planning (LANDEP) in the process of territorial planning. Ekológia (ČSSR) 1982, 1, 297-312.

40. Fabos, J.; Caswell, S. Composite Landscape Assessment: Assessment Procedures for Special Resources, Hazards and Development Suitability. Part II of the Metropolitan Landscape Planning Model (METLAND); Research Bulletin 637; Agricultural Experimentation Station, University of Massachusetts: Amherst, MA, USA, 1977.

41. Lyle, J.; Von Wodtke, M. An Information System for Environmental Planning. J. Am. Inst. Plan. 1974, 40, 394-413. [CrossRef]

42. Avessalomova, I.A.; Khoroshev, A.V.; Savenko, A.V. Barrier function of floodplain and riparian landscapes in river runoff formation. In Riparian Zones. Characteristics, Management Practices, and Ecological Impacts; Pokrovsky, O.S., Ed.; Nova Science Publishers: New York, NY, USA, 2016; pp. 181-210.

43. Khoroshev, A.V. Multiscale Organization of Landscape Structure in the Middle Taiga of European Russia. Landsc. Online 2019, 66, 1-19. [CrossRef]

44. Khoroshev, A.V.; Kositsky, A.G.; Lukyanova, A.N. Hydrological and Hydrochemical Rationales for Projecting Ecological Network in the Agrolandscape of the Southern Arkhangelsk Region. Proc. Moscow Univ. Geogr. Ser. 2019, 4, 63-72. (In Russian)

45. Khoroshev, A.V. Landscape Structure of the Vaga-Severnaya Dvina Interfluve; VINITI: Moscow, Russia, 2005. (In Russian)

46. Emelyanova, L.G.; Leonova, N.B. Forest islands in the agriculturally developed part of Arkhangelsk region as a habitat for rare animals. Bull. Mosc. Soc. Nat. Res. 2015, 120, 35-41. (In Russian)

47. Márquez, C.O.; García, V.J.; Schultz, R.C.; Isenhart, T. Assessment of Soil Aggradation through Soil Aggregation and Particulate Organic Matter by Riparian Switchgrass Buffers. Agronomy 2017, 7, 76. [CrossRef]

48. Ružička, M. Krajinnoekologicke Planovanie—LANDEP I (Systemovy Pristup v Krajinnej Ekologii); Združenie BIOSFERA: Nitra, Slovakia, 2000.

49. Emelyanova, L.G.; Nemchinova, A.V.; Khoroshev, A.V.; Zaitsev, V.A.; Kulyasova, A.A.; Emelyanov, A.A.; Oboturov, A.S. Objectives and landscape-Biogeographical rationales for the establishment of the Ustyansky natural park (middle taiga, Arkhangelsk region). Ecosyst.: Ecol. Dyn. 2019, 2, 155-207. (In Russian)

50. Haase, G. Landschaftsokologische Detailuntersuchung und naturraumliche Gliederung. Pet. Geogr. Mitt. 1964, 108, 8-30.

51. von Haaren, C.; Hoppenstedt, A.; Scholles, F.; Werk, K.; Runge, K.; Winkelbrandt, A. Landschaftsplanung und Strategische Umweltprïfung (SUP); UVP-Report 14 (1); UVP: Hamm, Germany; pp. 44-47.

52. Antipov, A.; Semenov, Y. The Russian school of landscape planning. In Environmental Security and Sustainable Land Use-With Special Reference to Central Asia; Nato Security through Science Series; Vogtmann, H., Dobretsov, N., Eds.; Springer: Dordrecht, The Netherlands, 2006.

53. Sayadyan, H.; Mammadov, R.; Elizbarashvili, N.; Garforth, M. Piloting Landscape Planning in the Countries of the South Caucasus; Sayadyan, H., Mammadov, R., Elizbarashvili, N., Garforth, M., Eds.; State Agrarian University of the Republic of Armenia: Yerevan, Armenia; G.A. Aliev Institute of Geography of the National Academy of Sciences of Azerbaijan: Baku, Azerbaijan; Ivane Javakhishvili Tbilisi State University: Tbilisi, Georgia, 2009.

54. Trombulak, S.C.; Baldwin, R.F. (Eds.) Landscape-scale Conservation Planning; Springer: Dordrecht, The Netherlands, 2010.

55. Turner, J.A. Geodiversity: The natural support system of ecosystems. In Landscape Planning with Ecosystem Services; Springer: Dordrecht, The Netherlands, 2019; pp. 253-266. 
56. Beven, K.; Lamb, R.; Leedal, D. Communicating uncertainty in flood inundation mapping: A case study. Int. J. River Basin Manag. 2015, 13, 285-295. [CrossRef]

57. Piechnik, D.A.; Goslee, S.C.; Veith, T.L.; Bishop, J.A.; Brooks, R.P. Topographic placement of management practices in riparian zones to reduce water quality impacts from pastures. Landsc. Ecol. 2012, 27, 1307-1319. [CrossRef] 